\title{
A nucleoside triphosphate for site-specific labelling of DNA by the Staudinger ligation
}

\author{
Samuel H. Weisbrod and Andreas Marx* \\ Received (in Cambridge, UK) 14th December 2006, Accepted 24th January 2007 \\ First published as an Advance Article on the web 9th February 2007 \\ DOI: $10.1039 / \mathrm{b} 618257 \mathrm{~g}$
}

\begin{abstract}
A novel nucleotide building block for enzymatic synthesis of azide modified DNA and subsequent conjugation via Staudinger ligation was developed.
\end{abstract}

Many studies of complex biological systems are only feasible through conjugation of biopolymers with other functional molecules like dyes or affinity tags. Linkage of a complex biomolecule with another molecular entity is often a challenging task. Albeit several bioconjugation methods are available, truly chemoselective methods are rarely represented. ${ }^{1,2}$ Recently, two reactions based on the specific reactivity of the azide moiety were introduced. ${ }^{3-5}$ One method is based on the [3+2] cyclo addition reaction of an azide and a terminal alkyne ${ }^{6}$ promoted by copper catalysis. $^{7,8}$ This reaction has been employed extensively and recently been extended for conjugation of DNA. ${ }^{9,10}$ On the other side, the so-called Staudinger ligation developed by Bertozzi ${ }^{11-13}$ readily occurs between an azide and a phosphine to form an azaylide that can be trapped by an acyl group to form a stable amide bond. This reaction has been employed in numerous applications e.g. for the conjugation of carbohydrates, $\operatorname{protein}^{14,15}$ and phage particles $^{16}$ as well as peptide ligation and immobilization. ${ }^{17-21}$ Recently, methods were devised to employ the Staudinger ligation for conjugation of DNA. It was shown that conjugation of an azide functionality via a suitable linker system enables conjugation of dyes to the $5^{\prime}$-end of single stranded DNA. ${ }^{22}$ Rajski et al. employed the Staudinger ligation to conjugate DNA with phenanthroline moieties for subsequent $\mathrm{Cu}(\mathrm{I})$ induced strand scission. ${ }^{23}$ Here we report on the development of a novel azide modified nucleoside triphosphate building block, that is readily incorporated into DNA enzymatically by a DNA polymerase. The resulting double stranded azide modified DNA can be smoothly conjugated with modified phosphines via the Staudinger ligation.

Our strategy to modify DNA site-specifically with azide functions by use of DNA polymerases for subsequent Staudinger ligation is depicted in Scheme 1B. The first step consists of a DNA polymerase reaction in which one of the natural nucleoside triphosphates (dNTPs) is substituted by a modified analogue that contains an azide functionality. Obviously the success of this step is contingent on the ability of a DNA polymerase to accept the modified nucleotide. The azide-modified double stranded DNA in turn should serve as substrate for Staudinger ligation with a suitably functionalized phosphine.

Chair of Organic Chemistry \& Cellular Chemistry, Department of Chemistry, University of Konstanz, 78457, Konstanz, Germany. E-mail: Andreas.Marx@uni-konstanz.de; Fax: +49 753188 5140; Tel: +497531885139

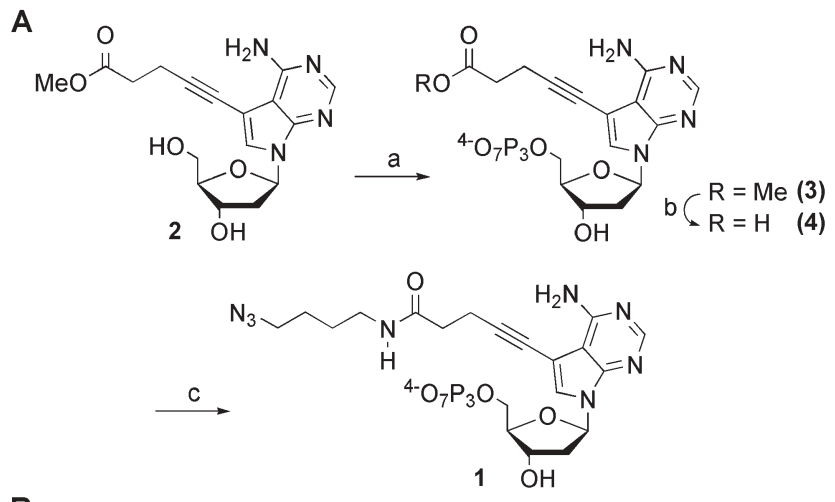

B

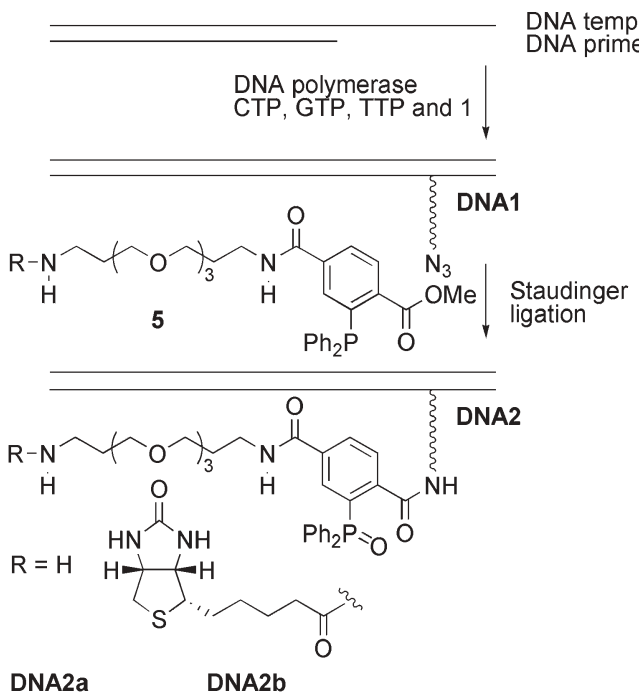

Scheme 1 (A) Synthesis of the modified nucleoside triphosphate. Reagents and conditions: (a) (i) $\mathrm{POCl}_{3}$, proton sponge, $\mathrm{PO}(\mathrm{OMe})_{3}, 0$ ${ }^{\circ} \mathrm{C}, 3 \mathrm{~h}$; (ii) $\left(n-\mathrm{Bu}_{3} \mathrm{NH}\right)_{2} \mathrm{H}_{2} \mathrm{P}_{2} \mathrm{O}_{7}, n-\mathrm{Bu}_{3} \mathrm{~N}, 30 \mathrm{~min}$; (iii) $1 \mathrm{M} \mathrm{TEAB}(27 \%)$; (b) $0.5 \mathrm{M}$ aqueous $\mathrm{NaOH}, \mathrm{rt}, 1 \mathrm{~h}(72 \%)$; (c) 4-azidobutylamine hydrochloride, EDC, pH 4, rt, 4 h (16\%). (B) Schematic depiction for labelling of DNA with phosphines $\mathbf{5} \mathbf{a}$ and $\mathbf{5 b}$.

Thus, first we developed the synthesis of the nucleoside triphosphate 1, a 2'-deoxyadenosine analogue (Scheme 1A). Since it has been shown that 7-modified 7-deaza-2'-deoxyadenosine derivatives are accepted by DNA polymerases ${ }^{24-28}$ we focused our synthesis on these kinds of analogues. Following a published procedure $^{24}$ we synthesised a 7-deaza-2'-deoxyadenosine 2 , which was readily converted into the corresponding triphosphate $\mathbf{3}$. After saponification $^{24}$ the azide moiety was introduced via EDC promoted amide bond formation of the resulting carboxylic acid and 4-azido-butylamine to form the desired triphosphate $1 .^{29}$ 

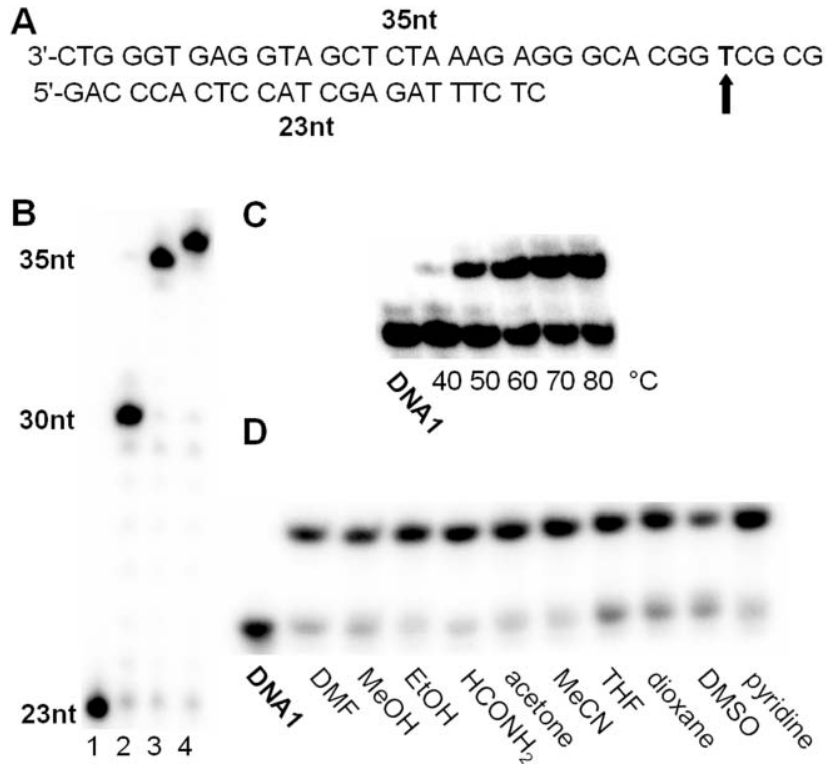

Fig. 1 (A) Sequences of primer template complex used to study incorporation of 1. (B) Denaturating PAGE analysis of primer extension reactions. Lane 1: $5^{\prime}-{ }_{-}^{32} \mathrm{P}$-labeled primer template complex at $72{ }^{\circ} \mathrm{C}$ for $30 \mathrm{~min}$. Lane 2: same as in lane 1 including dGTP, dTTP, dCTP and Pwo DNA polymerase. Lane 3: as in lane 2 including dATP. Lane 4: as in lane 2 including 1. (C) Staudinger ligation employing enzymatically synthesized dsDNA as shown in Fig. 1B lane 4 and phosphine 5a including 25\% DMF at various temperatures as indicated. (D) Staudinger ligation employing enzymatically synthesized dsDNA as shown in Fig. 1B lane 4 and phosphine 5 a at $60{ }^{\circ} \mathrm{C}$ including $25 \%$ of various co-solvents as indicated.

For further studies we first focussed on investigating the properties of $\mathbf{1}$. To test the ability of DNA polymerases to accept $\mathbf{1}$ as substrate and incorporate the respective nucleotides into a nascent DNA strand we set up a primer extension reaction, where a single $\mathrm{T}$ residue in the $35 \mathrm{nt}$ template stand calls for incorporation of the first dATP analogue after extending the $23 \mathrm{nt}$ primer strand by seven residues (Fig. 1). After testing several DNA polymerases we found that Pyrococcus woesei (Pwo) DNA polymerase is best suited for our endeavour. ${ }^{30}$ While reactions ${ }^{31}$ performed in the absence of any dATP analogue predominately abort before the template $\mathrm{T}$ after extending the primer strand by seven nucleotides, addition of natural dATP results in the formation of full-length product. Interestingly, substitution of dATP by 1 yields full-length product in a similar fashion as observed with the non-modified dATP. These results support earlier findings by Famulok et al. reporting the usage of $P w o$ DNA polymerase for the generation of highly functionalized DNA. ${ }^{24}$

After having achieved successful incorporation of the building block into double-stranded DNA we next investigated whether the enzymatically synthesized DNA is suitable for Staudinger ligation. ${ }^{32}$ In a first set of experiments the synthesized DNA was treated with phosphine $\mathbf{5 a}$ at various temperatures for $4 \mathrm{~h}$. We found that the reactions proceeded smoothly albeit with significant temperature dependence (Fig. 1C). However, best results were obtained after an increase of the reaction time to $12 \mathrm{~h}$ and a temperature of $60{ }^{\circ} \mathrm{C}$. Noteworthy, since the phosphine $\mathbf{5 a}$ is poorly soluble in water it was added to the reaction mixture as a solution in DMF resulting in a total $3: 1$ aqueous buffer to DMF ratio. Thus, next we investigated the influence of other co-solvents

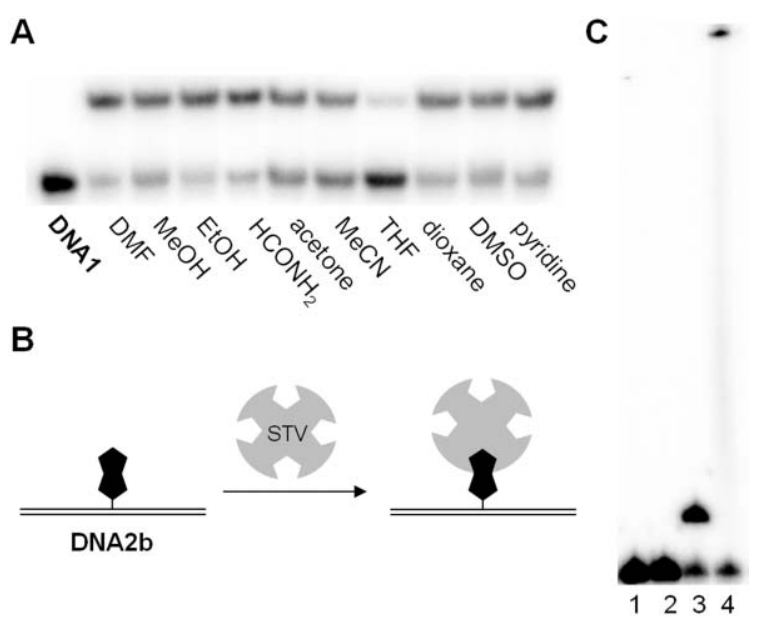

Fig. 2 (A) Denaturating PAGE analysis of Staudinger ligation with phosphine 5b. Conditions like Fig. 1D. (B) Schematic depiction for the biotin-streptavidin (STV) assay. (C) Conjugation of streptavidin on biotinylated DNA: Lane 1: DNA1 alone. Lane 2: DNA1 plus STV. Lane 3: DNA1 after treatment with 5 (formation of DNA2b). Lane 4: as lane 3 after addition of STV.

on the Staudinger ligation. While the reaction proceeded with $68 \%$ in the presence of DMF, conversion up to $80 \%$ was observed in the presence of acetonitrile, ethanol and pyridine (Fig. 1D).

Employing these optimized procedure we next investigated the Staudinger ligation between the enzymatically synthesized DNA1 and phosphine $\mathbf{5 b}$, that bears a biotin residue. The reaction proceeded with nearly the same efficiency as with the model phosphine 5a and up to $70 \%$ conversion was achieved using DMF or ethanol as co-solvent (Fig. 2A). The biotin moiety allows further conjugation with streptavidin (STV) functionalized materials and is often used for analysis and purification of biomolecules. ${ }^{33-35}$ Here we conjugated STV as proof for the successful Staudinger ligation (Fig. 2B).

The results of the incubation of DNA2b with a STV solution are shown in Fig. 2C. ${ }^{36}$ The control reaction with DNA1 and STV shows no change in comparison with DNA1 alone, whereas the biotinylated DNA shifts in presence of STV quantitatively to lower mobility. These observations prove the presence of a biotin moiety in the DNA treated with phosphine $\mathbf{5 b}$.

In conclusion, we describe a straightforward method to directly functionalize DNA with azide groups that are accessible for further conjugation via Staudinger ligation. Here we show that the developed azide-modified nucleoside triphosphate building block is readily incorporated into a growing DNA strand via a DNA polymerase directed DNA synthesis. The synthesized DNA in turn can be conjugated using phosphines that bear several functional groups e.g. biotin. The divised methods pave the way for efficient DNA conjugation under mild condition just by adding the two reaction partners without requiring further reagents. Currently we investigate whether conjugation of longer DNA fragments, that are obtained by PCR amplification, are amenable via the depicted approach.

\section{Notes and references}

1 C. M. Niemeyer, Bioconjugation Protocols (Methods in Molecular Biology Series Vol. 283), Humana Press, Totowa, 2004. 
2 E. T. Kool, DNA and Aspects of Molecular Biology (Comprehensive Natural Products Chemistry Vol. 7), Pergamon Press, Oxford, 2002.

3 R. Breinbauer and M. Köhn, ChemBioChem, 2003, 4, 1147-1149.

4 M. Köhn and R. Breinbauer, Angew. Chem., Int. Ed., 2004, 43, 3106-3116.

5 S. Bräse, C. Gil, K. Knepper and V. Zimmermann, Angew. Chem., Int. Ed., 2005, 44, 5188-5240.

6 R. Huisgen, Angew. Chem., Int. Ed. Engl., 1963, 2, 565-598.

7 V. V. Rostovtsev, L. G. Green, V. V. Fokin and K. B. Sharpless, Angew. Chem., Int. Ed., 2002, 41, 2596-2599.

8 C. W. Tornoe, C. Christensen and M. Meldal, J. Org. Chem., 2002, 67, 3057-3064.

9 J. Gierlich, G. A. Burley, P. M. E. Gramlich, D. M. Hammond and T. Carell, Org. Lett., 2006, 8, 3639-3642.

10 G. A. Burley, J. Gierlich, M. R. Mofid, H. Nir, S. Tal, Y. Eichen and T. Carell, J. Am. Chem. Soc., 2006, 128, 1398-1399.

11 E. Saxon and C. R. Bertozzi, Science, 2000, 287, 2007-2010.

12 E. Saxon, J. I. Armstrong and C. R. Bertozzi, Org. Lett., 2000, 2 , 2141-2143.

13 B. L. Nilsson, L. L. Kiessling and R. T. Raines, Org. Lett., 2001, 3, 9-12.

14 L. Liu, Z.-Y. Hong and C.-H. Wong, ChemBioChem, 2006, 7, 429-432.

15 C. Grandjean, A. Boutonnier, C. Guerreiro, J.-M. Fournier and L. A. Mulard, J. Org. Chem., 2005, 70, 7123-7132.

16 M.-L. Tsao, F. Tian and P. G. Schultz, ChemBioChem, 2005, 6, 2147-2149.

17 B. L. Nilsson, R. J. Hondal, M. B. Soellner and R. T. Raines, J. Am. Chem. Soc., 2003, 125, 5268-5269.

18 M. Köhn, R. Wacker, C. Peters, H. Schröder, L. Soulère, R. Breinbauer, C. M. Niemeyer and H. Waldmann, Angew. Chem., Int. Ed., 2003, 42, $5830-5834$

19 H. Kim, J. K. Cho, S. Aimoto and Y.-S. Lee, Org. Lett., 2006, 8, $1149-1151$

20 A. Watzke, M. Gutierrez-Rodriguez, M. Kohn, R. Wacker, H. Schroeder, R. Breinbauer, J. Kuhlmann, K. Alexandrov, C. M. Niemeyer, R. S. Goody and H. Waldmann, Bioorg. Med. Chem., 2006, 14, 6288-6306.

21 A. Watzke, M. Köhn, M. Gutierrez-Rodriguez, R. Wacker, H. Schröder, R. Breinbauer, J. Kuhlmann, K. Alexandrov, C. M. Niemeyer, R. S. Goody and H. Waldmann, Angew. Chem., Int. Ed., 2006, 45, 1408-1412.

22 C. C. Y. S. Wang, Tae Seok, Li Zengmin, Ruparel Hameer and Ju Jingyue, Bioconjugate Chem., 2003, 14, 697-701.

23 L. R. R. Comstock and R. Scott, J. Am. Chem. Soc., 2005, 127, 14136-14137.

24 S. Jäger, G. Rasched, H. Kornreich-Leshem, M. Engeser, O. Thum and M. Famulok, J. Am. Chem. Soc., 2005, 127, 15071-15082.

25 G. Giller, T. Tasara, B. Angerer, K. Muhlegger, M. Amacker and H. Winter, Nucleic Acids Res., 2003, 31, 2630-2635.

26 T. Gourlain, A. Sidorov, N. Mignet, S. J. Thorpe, S. E. Lee, J. A. Grasby and D. M. Williams, Nucleic Acids Res., 2001, 29, 1898-1905.
27 T. Kawate, C. R. Allerson and J. L. Wolfe, Org. Lett., 2005, 7, 3865-3868.

28 G. F. Kaufmann, M. M. Meijler, C. Sun, D.-W. Chen, D. P. Kujawa, J. M. Mee, T. Z. Hoffman, P. Wirsching, R. A. Lerner and D. Janda Kim, Angew. Chem., Int. Ed., 2005, 44, 2144-2148.

$29250 \mu \mathrm{l} 20.2 \mathrm{mM}(5 \mu \mathrm{mol})$ solution of nucleotide 4 was combined with $144 \mu \mathrm{l} 0.5 \mathrm{M}$ 4-azidobutylamine hydrochloride solution $(72 \mu \mathrm{mol})$ and $19 \mu \mathrm{l} 0.52 \mathrm{M}$ EDC solution $(10 \mu \mathrm{mol})$ and the $\mathrm{pH}$ was adjusted to 4 with $0.5 \mathrm{M} \mathrm{HCl}$. The solution was shaken for $4 \mathrm{~h}$ at $\mathrm{rt}$ until no more conversion was observed. Purification with DEAE-Sephadex column using a linear gradient from $0.1 \mathrm{M}$ to $1 \mathrm{M}$ TEAB buffer afforded the pure product as triethylammonia salt. Calculation of concentration based on the absorbance at $280 \mathrm{~nm}$ indicated a yield of $16 \%$ ( $c a .0 .8 \mathrm{mg}$ ). ${ }^{1} \mathrm{H}-\mathrm{NMR}\left(600 \mathrm{MHz}, \mathrm{CD}_{3} \mathrm{OD}\right) \delta \mathrm{ppm} 8.09(\mathrm{~s}, 1 \mathrm{H}), 7.67(\mathrm{~s}, 1 \mathrm{H}), 6.60$ $(\mathrm{dd}, J=7.2 \mathrm{~Hz}, J=6.4 \mathrm{~Hz}, 1 \mathrm{H}), 4.69$ (ddd, $J=5.9 \mathrm{~Hz}, J=2.8 \mathrm{~Hz}, J=$ $2.8 \mathrm{~Hz}, 1 \mathrm{H}), 4.23-4.28(\mathrm{~m}, 1 \mathrm{H}), 4.13-4.18(\mathrm{~m}, 1 \mathrm{H}), 4.06-4.10(\mathrm{~m}, 1 \mathrm{H})$, $3.12-3.38(\mathrm{~m}, 2 \times 2+24 \mathrm{H}), 2.50-2.56(\mathrm{~m}, 1 \mathrm{H}), 2.48(\mathrm{t}, J=6.8 \mathrm{~Hz}$ $2 \mathrm{H}), 2.72(\mathrm{t}, J=6.8 \mathrm{~Hz}, 2 \mathrm{H}), 2.31(\mathrm{ddd}, J=13.5 \mathrm{~Hz}, J=6.1 \mathrm{~Hz}, \mathrm{~J}=$ $3.3 \mathrm{~Hz}, 1 \mathrm{H}), 115-1.37(\mathrm{~m}, 36 \mathrm{H}){ }^{31} \mathrm{P}-\mathrm{NMR}\left(162 \mathrm{MHz}, \mathrm{CD}_{3} \mathrm{OD}\right): \delta \mathrm{ppm}$ $-8.9(\mathrm{~d}, J=18.6 \mathrm{~Hz}, 1 \mathrm{P}),-9.8(\mathrm{~d}, J=20.7 \mathrm{~Hz}, 1 \mathrm{P}),-21.7(\mathrm{~m}, 1 \mathrm{P})$ ESI-MS: $681.1[\mathrm{M}-\mathrm{H}]^{-}$(calc: 681.5 ).

$30 \mathrm{Taq}$ and Vent (exo-) DNA polymerases are also capable of incorporation of nucleotide 1 , but extend the primer strand over the $5^{\prime}$ end of the template with one additional $\mathrm{A}$.

31 Primer extension reactions: $20 \mu \mathrm{l}$ of the reaction contained $1 \mathrm{U}$ Pwo DNA polymerase, $1.6 \mu \mathrm{M}$ template with $1.2 \mu \mathrm{M}{ }^{32} \mathrm{P}$ labelled annealed primer, $250 \mu \mathrm{M}$ of the appropriate dNTPs in $1 \times P w o$ reaction buffer. The reaction was started by the addition of polymerase, run for $30 \mathrm{~min}$ at $72{ }^{\circ} \mathrm{C}$ in a thermal cycler and afterwards stopped by addition of $20 \mu \mathrm{l}$ stop solution $(80 \%$ [v/v] formamide, $20 \mathrm{mM}$ EDTA, $0.25 \%[\mathrm{w} / \mathrm{v}]$ bromophenol blue, $0.25 \%$ [w/v] xylene cyanol). Reactions were separated using a $12 \%$ denaturing PAGE. Visualization was performed using phosphorimaging.

32 For Staudinger ligation reactions the product of primer extension reaction, in which dATP was replaced with 1 , was freed from excess 1 with Microspin G25 columns. $5 \mu$ of this solution was mixed with $2.5 \mu \mathrm{l}$ of $10 \mathrm{mM}$ stock solution of phosphine $\mathbf{5}$ in the appropriate organic solvent and $2.5 \mu \mathrm{l} 1 \mathrm{M} \mathrm{NaHCO} / \mathrm{Na}_{2} \mathrm{CO}_{3}$ buffer at $\mathrm{pH}$ 9. The reaction was incubated for the specified time at the desired temperature. Previous to separating on $12 \%$ denaturing PAGE $10 \mu \mathrm{l}$ stop solution was added.

33 C. M. Niemeyer, J. Biotechnol., 2001, 82, 47-66.

34 C. M. Niemeyer, Trends Biotechnol., 2002, 20, 395-401.

35 C. M. Niemeyer, R. Wacker and M. Adler, Angew. Chem., Int. Ed, 2001, 40, 3169-3172.

36 For STV conjugation Staudinger ligation was carried out as described with DMF as organic co-solvent, phosphine $\mathbf{5 b}$ and $12 \mathrm{~h}$ reaction time at $60{ }^{\circ} \mathrm{C}$. Excess phosphine and buffer salts were removed with Microspin G25 columns and all solvents were removed. The re-dissolved DNA was incubated with 10 fold excess of STV in TBE buffer. After addition of stop solution separating was performed with $12 \%$ denaturing PAGE. 